\title{
Editorial
}

\section{Two Fortuitous Papers in 1917 That Conceived Diagnostic Cytopathology}

\author{
Nikolaos Chantziantoniou \\ Department of Pathology, Sidra Medical and Research Center, Doha, Qatar
}

The International Academy of Cytology and its journal, Acta Cytologica, were founded in 1957. Under the inaugural editorship of Dr. George L. Wied, Acta Cytologica started out as a forum to converge invited discussions of theoretical and practical problems in the flourishing discipline of diagnostic cytopathology [1]. Now, 60 years on, this commemorative diamond jubilee issue celebrates a journey through the historical and scientific events that ultimately transcended into contemporary practice [1-8].

The odyssey thus far has revealed nothing short of legendary.

After a transatlantic voyage from Athens, Greece, on the ocean liner Athenai, Dr. George N. Papanicolaou and his wife, Andromache, reached New York on October 19, 1913. They were registered as newly arriving immigrants. The hardships of a new life, in a new homeland, and a new language soon became real and the couple faced basic needs that could not go overlooked. A sense of belonging was one such need; financial resources to sustain it soon became another $[2,3]$.

Between odd, meager employment opportunities that included writing biology articles, selling rugs, and playing the violin in public places, Papanicolaou approached the distinguished zoologist Dr. Thomas H. Morgan of Columbia University for possible assistance [2, 3]. This encounter proved to be most fortunate, but that was not entirely because of chance.

\section{KARGER}

(c) 2017 S. Karger AG, Basel

E-Mail karger@karger.com

www.karger.com/acy
Morgan had studied the genetics of Drosophila fruit flies and in his new book titled Heredity and Sex published in 1913 he had included 2 pages citing Papanicolaou's PhD thesis work in Germany on Daphnia water fleas. This commonality formed a profound bond between these scientists. Morgan eventually introduced Papanicolaou to Dr. William J. Elser, who then hired him as part-time laboratory technician in the Department of Pathology and Bacteriology in the New York Hospital. Impressed by Papanicolaou's technical and analytical skills, Elser brought Papanicolaou to the attention of Dr. Charles R. Stockard at Cornell Medical College, New York, for possible full-time employment in a more formal research setting. Stockard was the Chairman of the Department of Anatomy and had also studied in Germany. These men shared similar theories of biology and of Mendelian genetics [2, 3, 5, 7].

In September of 1914, Stockard hired Papanicolaou as an assistant in the Department of Anatomy. These events unfolded essentially within the first year of Papanicolaou's arrival to the USA - achievements unusually recorded in the lives of new immigrants at the turn of the 20th century in the fields of science and medicine. Certainly, neither these events nor Papanicolaou were usual; something unique was astir. Moreover, World War I was raging back in Europe, shunning any prospect of the couple returning back to their homeland. Their new life was to stay the course - regardless of hardship, regardless of purpose $[2,3]$. 
It was not long before Stockard also noticed Papanicolaou's abilities but, equally, his impatience and utter desire for scientific challenge. As Stockard managed a large colony of experimental guinea pigs at Cornell, and as he studied the influence of alcohol on chromosomes and transmission of aberrations to guinea pig progeny, he agreed for Papanicolaou to extend his $\mathrm{PhD}$ research work in sex differentiation through the study of chromosomes in guinea pigs. Papanicolaou welcomed this proposition. He also requested the collaboration of an assistant to help with the technical methods. Cornell obliged allowing Andromache to work alongside her husband on a volunteer, unpaid basis starting in November 1914.

In the following 44 years at Cornell, the husband-andwife team went on to establish not only gynecological cytopathology and the Pap test, but also the scientific foundations of an entire diagnostic medical profession [2$4,8]$.

Among the principal foundations of cytopathology is the eponymous 5-dye Papanicolaou staining method [9]. The inception and evolutionary development of the Pap stain is explored through another article in this issue of Acta Cytologica and, parenthetically, 100 years since the emergence of 2 fortuitous research papers published by Papanicolaou in 1917 that ultimately conceived modern diagnostic cytopathology.

The author is sincerely obliged to Dr. R. Marshall Austin, of the University of Pittsburgh Medical Center, for facilitating access to various literature and artifacts left behind by Dr. G. N. Papanicolaou. From the author's quest to research and piece together historical building blocks of the cytopathology saga, insights of Papanicolaou's rationalizations have emerged. Researched materials include anecdotal scientific writings in English and Greek, photographs, hand-written personal letters in Greek, and few but otherwise unavailable live recordings either of Papanicolaou or of others honoring him or his work. Furthermore, by sorting through impressions of the man and scientist as put forward by those who either worked or lived with him in New York, a personality has been shaped that cytopathology, now a global entity, ought to be cognizant of $[1,3,6,8,10-12]$.

Dr. George N. Papanicolaou was a modest man molded around the morals and principles that characterized his Hellenic upbringing and teachings. These principles revolved around a core sense of dignity, obligation, and destiny. He was driven by a voracious appetite for scientific research and knowledge and a need to discover something as yet unknown that he could develop for the betterment of humanity. These humble convictions gov-

Two Papers in 1917 That Conceived Cytopathology erned his life since childhood; these convictions also led to various pivotal decisions that he had to consider throughout his career. Papanicolaou yearned to conquer the sea; subconsciously perhaps, he yearned to conquer himself. He regarded human strength and ability as limitless. He rarely disregarded intuition or ignored unfairness. He also refused to mind pain, or impediments, favoring a purpose bestowed upon him through his mere existence in the universe. Alas, many of his philosophical standpoints caused both him and Andromache substantial pain and periodic debility, but never would they waver through to his death on February 18, 1962 [2, 3, 8]. Papanicolaou was also very astute, sensing opportunity spontaneously. He also had an intelligent sense of comicality that is detectable from within his scientific writings. These overall attributes helped him navigate his career course and see beyond milestones. Oftentimes, it seemed, he was living ahead of his time, simply searching for, and living through, ways by which to achieve advancing, selfimposed targets.

Stockard's proposition at Cornell was but one of Papanicolaou's renaissances. It created a purpose and a direction at a time when his professional outlook in their new life appeared blurred. Papanicolaou had written numerous letters to his parents pleading for their patience as he searched for his purpose in life. He was never to see them again. And purpose does not always elucidate direction. Yet, as Papanicolaou yearned for direction, direction he indeed discovered.

Papanicolaou's initial research plan at Cornell involved the study of mitotic division at ovulation. This necessitated surgical removal of guinea pig ovaries at a specific time during their estrous cycle. None of these parameters were known to him or to his peers, but such scientific unknowns attracted him naturally. He knew these mammals menstruated, though feebly. He therefore questioned whether evidence of menstruation could somehow be detected in vaginal secretions. These questions led him to a local surgical supply store from where he obtained a small nasal speculum. His plan was technically simple; however, it concealed a science of extraordinary complexity - as gradually became evident over the course of the years that led to the formalization of the Pap test in 1954. Using the speculum, Papanicolaou collected miniscule vaginal fluid samples from the experimental animals daily. Fluids were spread thinly onto glass slides and stained with hematoxylin and eosin stains. From meticulous, iterative analysis of the physical characteristics of vaginal fluids over time, Stockard and Papanicolaou described ovulation and the menstrual cycling of guinea 
pigs precisely by analyzing exfoliated epithelial cells. Their findings were published in an obscure 3-page report in Science in 1917 (entitled "A Rhythmical 'Heat Period' in the Guinea-Pig") [13].

These discoveries inspired Papanicolaou. The uncovered science was certainly not trivial. He had succeeded in triangulating vaginal epithelial cytomorphology with ovarian function and relevant histology. But Papanicolaou's intuition sat uneasy with a 3-page report that did not adequately reflect his efforts or communicate the analytical potential harnessed by epithelial cells entrapped in vaginal fluids or their reflection of underlying physiology and endocrinology. These scientific novelties vastly surpassed his basic research plan of studying chromosomal morphology. A gateway leading towards another scientific frontier had appeared. As such, Papanicolaou opted to expand upon the data in substantially greater detail, producing his first discussions of cytologic interpretation and staining methods, supported by early photomicrographs of epithelial cells and their respective uterine histology. Once again coauthored with Stockard, Papanicolaou's efforts produced an elegant 58-page report published in the American Journal of Anatomy in 1917 (entitled "The Existence of a Typical Oestrous Cycle in the Guinea-Pig - With a Study of its Histological and Physiological Changes") [14].

Ultimately, Papanicolaou's research work achieved its objective: it facilitated precise timing of guinea pig ovulation. But this experimental work drew him into the realm of another discipline while at its inception, with equally enthralling unknowns and seemingly limitless possibilities. Though a researcher, Papanicolaou was also a physician, but not a pathologist. It would thus seem natural for him to question whether the same physiological triangulations may also be revealed through vaginal fluid analysis in women. It was this simple spark of curiosity that unraveled waves upon waves of scientific triumphs and disappointments that ultimately founded the discipline of diagnostic cytopathology $[2,3,7,8]$.

The aforementioned papers published in 1917 received considerable praise, but as credit was directed towards the primary author, i.e., Stockard, knowledge of this distressed Papanicolaou [3]. He was unnerved that as a coauthor he would not muster the awareness necessary to enhance his career given his lack of North American credentials. This unfair setback was poignant enough that he was poised to abandon Cornell. Nonetheless, after bringing the matter to Stockard's attention, he was granted professional autonomy and the chairman's name would no longer need to precede his. Based on this un-

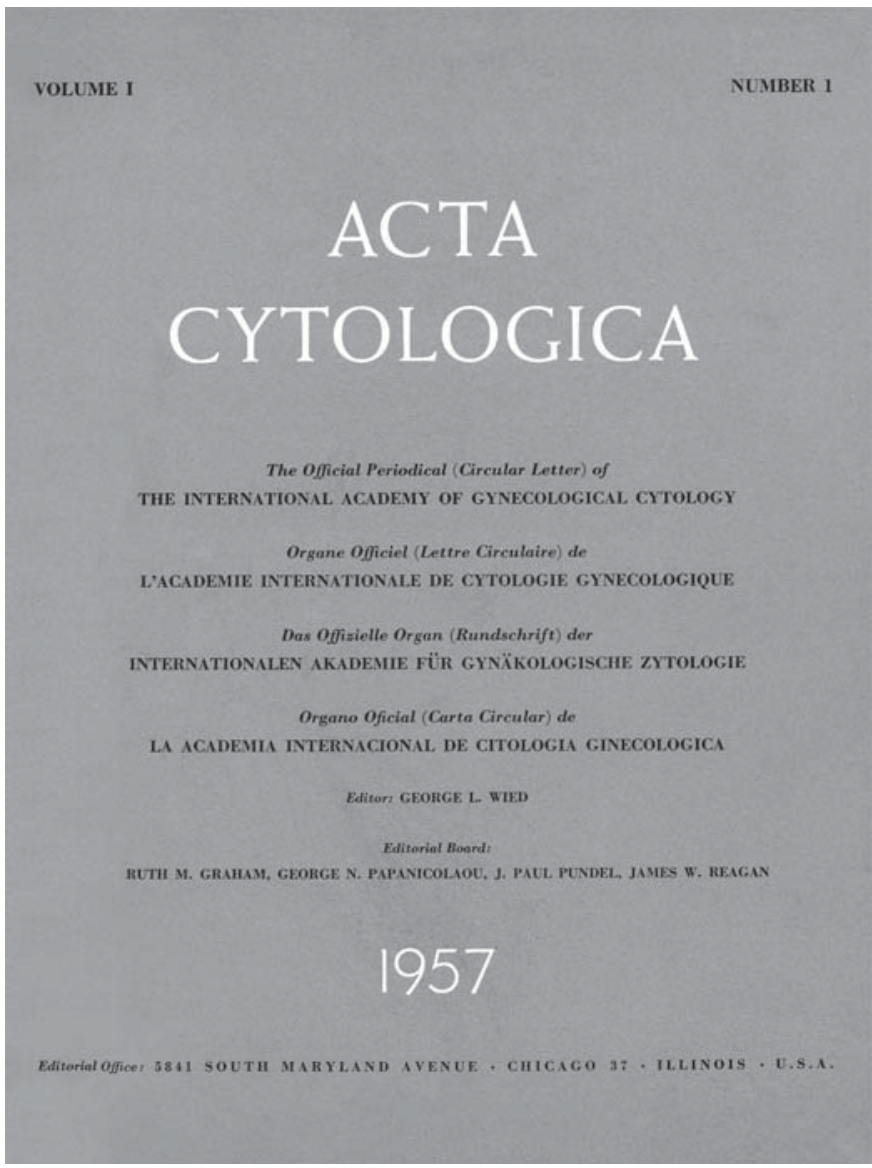

Fig. 1. Title page of the inaugural issue of Acta Cytologica [15].

derstanding, and riding upon Stockard's acknowledgement, Papanicolaou thrived on a renewed sense of direction $[2,3,8]$.

The 1917 papers also proved seminal. Papanicolaou rationalized concepts that transcended into the fundamentals of interpretive cytopathology and its subspecialties as practiced today. His initial studies with guinea pigs sparked his experimentation with unconventional staining methods. They in turn facilitated correlation between underlying endocrinology, histology, and the cytomorphology of epithelial cells. Since 1920, and for 21 years thenceforth, Andromache contributed the study material for the development of benign, baseline gynecological cytomorphology. The discovery of cervical cancer cells in 1925 prompted a renewed assault to develop diagnostic tools by which to spot and differentiate between malignant and benign cells arising from the uterine cervix, and from other anatomic sites. And the development of alcoholic fixation and counter-staining in the 5-dye Pap stain 
method, introduced in 1942, revealed cytomorphology upon which cellular differentiation and nuclear chromatin grading became possible and reproducible [2].

These multifaceted foundations supported the expansion of cytopathology into varied clinical and diagnostic forays.

Soon after their retirement from Cornell in 1957, Andromache and Dr. Papanicolaou took their first formal holiday since arriving to the USA in 1913. Setting off from New York in July 1957 on another transatlantic voyage on the ocean liner Queen Mary, they travelled eastward to Belgium. There, Papanicolaou attended a conference and collaborated in the founding of the International Academy of Cytology and Acta Cytologica. Papanicolaou served on the Editorial Board of Acta Cytologica from the onset, as evident on the title page of volume 1, number 1, 1957 (Fig. 1) [15]. From Belgium, the couple travelled back to Greece to visit their birth land and their relatives [11].

Of course, over the years, cytopathology has evolved from the substantial contributions of many cytologists. A remarkable bibliography now attests to the events and dynamics that ultimately branded this discipline with its unique identity, scope, and purpose [1]. All throughout this journey, Papanicolaou remained a central figure: a towering, compelling force.

Dr. George N. Papanicolaou was blessed with natural analytical skills, and the personality to brave the obstacles inherent to medical research and method development [8]. He was also blessed with the affection and trust that many relatives, associates, and organizations bestowed upon him from their varied perspectives. Andromache's selfless dedication and contribution were elemental in the development of gynecological cytopathology. Papanicolaou's accolades are far too numerous for this editorial but they are astounding nonetheless $[1,2,6,11,12]$.

Humanity, and diagnostic cytopathology along with its significance in clinical medicine, shall remain indebted to these immigrants and to their adopted homeland that embraced and nurtured their eagerness for scientific research and human betterment.

Acta Cytologica remains at the forefront of this odyssey, with many more milestone anniversaries yet to be celebrated in due course.

Heartfelt congratulations are in order.

\section{References}

1 Naylor B: The century for cytopathology. Acta Cytol 2000;44:709-725.

2 Boon ME, Chantziantoniou N: Papanicolaou Revisited. Leyden, Coulomb, 2013.

3 Carmichael DE: The Pap Smear: Life of George N. Papanicolaou. Springfield, Thomas, 1973.

4 Chantziantoniou N: Lady Andromache (Mary) Papanicolaou: the soul of gynecological cytopathology. J Am Soc Cytopathol 2014; 3:319-326.

5 Chantziantoniou N: The Pap test: celebrating 100 years in the making and beyond. J Am Soc Cytopathol 2014;3:143-150.

6 Koss LG: Papanicolaou's 100th birthday. Acta Cytol 1983;27:217-219.
7 Chantziantoniou N: The wars against cervical cancer. J Am Soc Cytopathol 2014;3:275-279.

8 Austin RM, Chantziantoniou N: George Nicholas Papanicolaou: the unlikely story of an intellectual immigrant; one driven to contribute on a large stage; one who finally succeeded by scientifically inspiring numerous cooperating individuals and organizations. J Am Soc Cytopathol 2014;3:331-334.

9 Papanicolaou GN: A new procedure for staining vaginal smears. Science 1942;95:438-439.

10 Traut HF: Necrologia: obituary for George N. Papanicolaou, MD, PhD. Oncology 1963;16: 351-353.

11 Papanicolaou-Kokkori M: George N. Papanicolaou, MD, PhD: Life and Career - The Way to the Pap Test. New York, Hellenic Medical Society of New York, 2008.
12 Koprowska I: A Woman Wanders through Life and Science. Albany, State University of New York Press, 1997.

13 Stockard CR, Papanicolaou GN: A rhythmical 'heat period' in guinea pigs. Science 1917;46: 42-44.

14 Stockard CR, Papanicolaou GN: The existence of a typical oestrous cycle in the guineapig: with a study of its histological and physiological changes. Am J Anat 1917;22:225283.

15 Hajdu SI: Acta Cytologica 40 years ago: Volume 1, Number 1, 1957. Acta Cytol 1997;41: 621-622. 